\title{
Problems Encountered during In vitro Culture Establishment in Terminalia arjuna
}

\author{
Meena Choudhary ${ }^{1 *}$, Inder Dev Arya ${ }^{1}$ and Sarita Arya ${ }^{1}$ \\ ${ }^{1}$ Genetics and Tree Improvement Division, Arid Forest Research Institute, Jodhpur-342005, India.
}

Authors' contributions

This work was carried out in collaboration among all authors. Author MC designed the study, performed the statistical analysis, wrote the protocol and wrote the first draft of the manuscript. Authors IDA and SA supervised. All authors read and approved the final manuscript.

Article Information

DOI: $10.9734 / A R R B / 2020 / v 35 i 1230320$

Editor(s):

(1) Dr. Md. Torequl Islam, Federal University of Piaui, Brazil. Reviewers:

(1) Oluwafemi Adeyemi Ajenifuja, Federal Polytechnic, Ado-Ekiti, Nigeria. (2) Orsolya Borsai, University of Agricultural Sciences and Veterinary Medicine of Cluj-Napoca, Romania. Complete Peer review History: http://www.sdiarticle4.com/review-history/64676

Original Research Article

Received 25 October 2020

Accepted 29 December 2020

Published 31 December 2020

\begin{abstract}
The main aim of present study was to overcome the problems associated with the in vitro culture initiation in Terminalia arjuna. The micropropagation of tree species is not easy as shrubs and herbs. Many problems encountered from explant collection to in vitro culture establishment. The problems that have been occurred during $T$. arjuna micropropagation were culture contamination, phenolic exudation, bud growth inhibition, shoots yellowing and leaf fall. All these problems have been solved by applying certain treatments prior to explant collection and inoculation. The mother tree was lopped in November months (six months prior to explant collection) to remove any inhibitory substance and release bud growth. Different sterilizing agents were used to minimize the bacterial and fungal contamination. Some modification in culture media (use of different concentration of $\mathrm{NH}_{4} \mathrm{NO}_{3}$ and $\mathrm{KNO}_{3}$ salts and adenine sulphate) was done. Surface sterilization of nodal explants collected from lopped branches with $0.1 \% \mathrm{HgCl}_{2}$ for $8 \mathrm{~min}$., treatment with chilled antioxidant solution (Ascorbic acid, Citric acid and PVP) and half strength of $\mathrm{NH}_{4} \mathrm{NO}_{3}$ and $\mathrm{KNO}_{3}$ salts of MS medium supported $100 \%$ bud break response with proliferation of green and healthy in vitro shoots. Removing these hurdles already in the initial stage of micropropagation is very important and maximize mass in vitro propagation of this medicinally important Arjun tree.
\end{abstract}


Keywords: Micropropagation; lopping; phenolic exudation; culture medium.

\section{INTRODUCTION}

Terminalia arjuna is an important medicinal plant species which holds reputed position in medicinal industry. It is commonly known as Arjuna or Arjun tree. $T$. arjuna is a large evergreen tree with height of about 20- $26 \mathrm{~m}$ and girth about 3 $\mathrm{m}$. It grows mostly in moist cool areas. Its wood is more Havier, harder and shock resistance than teak. The leaves are oblong in shape, cordate and $10-15 \mathrm{~cm}$ long. The flowers are small, pale yellow and borne on pendulous terminal and axillary spikes. Each spikes consists of $45 \pm 3.5$ flowers. Fruits are woody, winged, green when young, but become brownish- black at maturity. Seeds are natural photoblastic with 50-60\% germination capacity. All parts of this tree have medicinal properties but the bark of this tree is the most valuable part, containing many secondary metabolites such as polyphenols, flavonoids, tannins, triterpenoids, saponins, sterols [1], minerals and amino acids (tryptophan, tyrosine, histidine and cysteine) which have antioxidant, hypotensive, anti-atherogenic, antiinflammatory, anti-carcinogenic, anti-mutagenic and gastro-productive effects [2]. The bark grows in two rainy seasons thus yield can be obtained on three-year cycle. Arjuna is one of the major tannin yielding trees. Bark (22-24\%), leaf (10$11 \%)$ and fruit $(7-20 \%)$ contains tannins. Although, Arjuna can easily be found across the Indian subcontinent but due to its high medicinal value, its population is declining sharply. To replenish its rapid loss and to meet medicinal requirements, its large-scale propagation is highly needed, however conventional propagation methods have some loopholes as inefficiency in rooting by cuttings and air-layering methods [3]. In this context, nonconventional propagation methods like micropropagation are the only hope for mass production. Micropropagation of tree species is generally not an easy task. The woody nature of tree species hindered its in vitro response. The micropropagation of $T$. arjuna is influenced by many factors which determine the propagation success rate. Previous studies on micropropagation of $T$. arjuna [3,4] described complete protocol but no reports have been found to report any problems associated with its micropropagation and their remedies. Therefore, the main aim of this study was to offer a solution for the problems occurred during in vitro propagation of $T$. arjuna due to the recalcitrant nature of this species limiting thus culture establishment and mass production. This study is the continuation of previous research works done in 2015 [5], 2018 [6], 2020 [7] including a complete micropropagation and factor influencing ex vitro rooting in Arjun tree.

\section{MATERIALS AND METHODS}

Nodal explants containing axillary buds were collected from $T$. arjuna growing at Ummaid garden, Jodhpur. These explants were pretreated to remove any bacterial or fungal contamination and to enhance the in vitro response of nodal explants. The axillary shoot proliferation was achieved on MS medium containing $8.88 \mu \mathrm{M}$ BAP. The culture vessels containing explants were kept in culture room for 4 weeks at $25 \pm 2^{\circ} \mathrm{C}$ temperature and $16 \mathrm{hr}$. light conditions.

\subsection{Bacterial and Fungal Contamination}

In the present study different sterilizing agents with pre treatments containing Bavistin and streptomycin were tried successfully to overcome the problem of fungal and bacterial infection. To obtain aseptic bud break, two different sterilizing agents like $\mathrm{HgCl}_{2}$ and $\mathrm{NaOCl}$ were used. Nodal explants containing axillary buds were treated with $0.1 \% \mathrm{HgCl}_{2}$ and $5 \% \mathrm{NaOCl}$ sterilizing agents for different time period ranging from 4 $\min$ to $10 \mathrm{~min}$ under Laminar air flow hood. After the treatment with sterilizing agents, nodal segments were washed with autoclaved distilled water, so as to remove the traces of mercuric chloride and then cultured on medium.

\subsection{Bud Growth Inhibition}

A good healthy tree was selected as mother tree and was lopped during November. New shoots regenerated from cuts (lopped branches) and old shoots (unlopped branches) in May were chosen as source for nodal segments. These explants were cultured on MS medium.

\subsection{Browning of Culture}

Different antioxidants and absorbents were used to eliminate the problem of phenolic exudation and culture browning. The nodal segments containing axillary bud were treated with chilled $\left(4^{\circ} \mathrm{C}\right)$ solution of ascorbic acid $(100 \mathrm{mg} / \mathrm{l})$, citric acid $(50 \mathrm{mg} / \mathrm{l})$ and PVP (25 mg/l) for $10-30 \mathrm{~min}$. These antioxidants and absorbent were also 
added to the culture medium supplemented with $2.0 \mathrm{mg} / \mathrm{l} \mathrm{BAP}$.

\subsection{Yellowing of Shoots}

The different concentration of nitrate salts of MS medium was used to prevent the yellowing of newly proliferated shoots under in vitro condition. Two major salts $\mathrm{NH}_{4} \mathrm{NO}_{3}$ and $\mathrm{KNO}_{3}$ of $\mathrm{MS}$ medium were incorporated in induction medium at $1 \times\left(1650 \mathrm{mg} / \mathrm{NH}_{4} \mathrm{NO}_{3} \text { and } 1900 \mathrm{mg} / \mathrm{K} \mathrm{KNO}\right)_{3}$, 1/2x (825 mg/l $\mathrm{NH}_{4} \mathrm{NO}_{3}$ and $\left.950 \mathrm{mg} / \mathrm{l} \mathrm{KNO}_{3}\right)$ and $1 / 4 \times\left(412.5 \mathrm{mg} / \mathrm{l} \mathrm{NH}_{4} \mathrm{NO}_{3}\right.$ and $475 \mathrm{mg} / \mathrm{l} \mathrm{KNO}_{3}$ ) concentration to improve axillary shoot proliferation response.

\subsection{Leaf Fall in In vitro Grown Shoot}

The effect of adenine sulphate was studied on axillary shoot proliferation. For this, different concentration of adenine sulphate $(25,50,100$ $\mathrm{mg} / \mathrm{l}$ ) was added in modified MS medium supplemented with BAP $2.0 \mathrm{mg} / \mathrm{l}$.

\subsection{Statistical Analysis}

Total 15 replicate were used for each treatment and each treatment repeated three times. The data of each experiment were recorded after 4 weeks. The resultant data were analyzed through one-way analysis of variance (ANOVA) using Statistical Packages for Social Sciences Software (SPSS 17.0). The results are expressed as mean \pm SE of three experiments. The significant differences between the means were assessed by Duncan's multiple range test $(P=0.05)$.

\section{RESULTS AND DISCUSSION}

\subsection{Bacterial and Fungal Contamination}

Explants sterilized with $\mathrm{NaOCl}$ for 6 min gave $82.22 \%$ axillary bud break response. When $\mathrm{NaOCl}$ was used to surface sterilize the explants for 8-10 min the explants decolorized and died after 10 days of inoculation. Out of the two sterilizing agents tested, $0.1 \% \mathrm{HgCl}_{2}$ proved to be more effective and gave the maximum number of aseptic explants. Maximum 100\% viable nodal segments containing axillary buds were obtained when explants were treated with $0.1 \% \mathrm{HgCl}_{2}$ for $8 \mathrm{~min}$. The increase of $\mathrm{HgCl}_{2}$ treatment duration above 8 min resulted in death of the explants which decreased the percentage survival of axillary buds (Table 1).
Use of streptomycin and Bavistin as pre disinfectant has been reported earlier also Pithecellobium dulce [8] and Melia dubia [9]. Heavy bacterial and fungal contamination of nodal segments collected from field grown mature tree was one of the major problems in the in vitro propagation of $T$. arjuna. Out of two sterilizing agents used for different time duration, $0.1 \% \mathrm{HgCl}_{2}$ for 8 min gave maximum $100 \%$ aseptic cultures. These results are in agreement with those of other reports where $0.1 \% \mathrm{HgCl}_{2}$ was very effective for sterilization of explants of Holarrhena antidysenterica [10] and Dalbergia sissoo [11].

\subsection{Release of Bud Growth Inhibition}

The management of mother tree is the main prerequisite for axillary shoot proliferation. When explants were cultured for axillary shoot proliferation, explants collected from unlopped trees were difficult to sterilize and showed poor bud break response with higher contamination. The nodal segments containing axillary buds collected from lopped trees responded better in terms of bud break percentage response with minimum contamination. Maximum $100 \%$ bud break response was obtained in nodal explants cultured from lopped tree (Table 2). The multiple axillary buds were proliferated form lopped tree whereas 2-3 shoots were proliferated from unlopped tree which did not elongate and multiply on further subculture on multiplication medium (MMS medium with1.0 mg/l BAP + 0.1 mg/l NAA).

The lopping of mother tree affects the axillary shoot proliferation response. The limited bud break in nodal explants collected from unlopped branches is due to their aged tissues present in it which block the activation of meristem. Phulwaria et al. [12] observed that the explants collected from mature and aged tree carried recalcitrant microbes and it was difficult to get them surface sterilized which was another reason for obtaining low percentage of aseptic explants. Rathore et al. [13] suggested lopping as a method of removing or diluting the inhibitors/ bud arresting factors. The young shoots collected from lopped tree produced less phenolic exudation and responded to bud multiplication. Saha [14] also observed that aged explants leached out more phenolics in the medium. Purohit et al. [15] had suggested trimming as a method of rejuvenation/ reinvigoration of mature adult woody plants. Vibha et al. [16] obtained multiple shoots from nodal shoot segments of lopped tree of Dalbergia sissoo. 
Table 1. Effect of different sterilization agents and sterilization time on the survival percent of explants (axillary buds) of Terminalia arjuna. Data recorded after 4 weeks from inoculation

\begin{tabular}{llll}
\hline $\begin{array}{l}\text { Sterilizing } \\
\text { agents }\end{array}$ & $\begin{array}{l}\text { Time duration of } \\
\text { sterilization } \\
\text { (min) }\end{array}$ & $\begin{array}{l}\text { Survival \% of aseptic } \\
\text { axillary buds } \\
\text { (explants) }\end{array}$ & Observation \\
\hline $\mathrm{HgCl}_{2}$ & 4 & $46.66 \pm 0.08^{\mathrm{bc}}$ & Mostly contaminated \\
& 6 & $86.66 \pm 0.05^{\mathrm{a}}$ & Green and contaminated \\
& 8 & $100.00 \pm 0.00^{\mathrm{a}}$ & Green and less contaminated \\
\hline $\mathrm{NaOCl}$ & 10 & $53.33 \pm 0.08^{\mathrm{b}}$ & Few dead \\
\hline & 6 & $60.00 \pm 0.07^{\mathrm{b}}$ & Green and contaminated \\
& 8 & $82.22 \pm 0.05^{\mathrm{a}}$ & Green and less contaminated \\
& 10 & $55.55 \pm 0.07^{\mathrm{b}}$ & Decolorized and less contaminated \\
\hline
\end{tabular}

Table 2. Effect of management of mother tree on axillary shoot proliferation of Terminalia arjuna

\begin{tabular}{llll}
\hline Explants & $\begin{array}{l}\text { Bud break } \\
\text { response (\%) }\end{array}$ & $\begin{array}{l}\text { Mean shoot } \\
\text { no. }\end{array}$ & $\begin{array}{l}\text { Mean shoot length } \\
\text { (cm) }\end{array}$ \\
\hline Nodal segments from lopped tree & $77.78 \pm 0.06$ & $2.42 \pm 0.17$ & $0.55 \pm 0.01$ \\
Nodal segments from non lopped tree & $100 \pm 0.00$ & $5.51 \pm 0.16$ & $0.82 \pm 0.02$ \\
\hline \multicolumn{2}{c}{ Values in column: mean \pm standard error }
\end{tabular}

\subsection{Browning of Medium}

During the culture establishment problem of phenolic exudation was encountered as the cut end of all explants exhibited browning in the culture media and subsequently the entire explant necrosed and died. This problem of phenolic exudation was overcome by keeping the explants in a solution of (chilled $4^{\circ} \mathrm{C}$ ) ascorbic acid (100 mg/l), citric acid (50 mg/l) and PVP (25 $\mathrm{mg} / \mathrm{l}$ ) for 10-30 min prior to inoculation on medium. It was observed that pre soaking of explants in a solution of ascorbic acid, citric acid and PVP for 20 min checked the phenolic exudation and gave $100 \%$ axillary bud break. Explants presoaked in this solution for more than 20 min delayed the in vitro bud break response (Table 3).

The main difficulty encountered during culture establishment was the exudation of phenolic into the medium. Some plants, particularly tropical species like Mango, T. catappa, contain high concentration of phenolic substances that are oxidized when cells are wounded or senescent. Isolated tissue then became brown or black and failed to grow. Browning has been described as enzymatic oxidation of phenolic substances by polyphenol oxidase [17]. PPO (polyphenol oxidase) is mainly in the vacuoles, while the enzyme is localized in plastids or chloroplasts. They do not come in contact with each other, but during excision cells are injured, and the browning reaction is initiated [18]. Besides polyphenol oxidase, phenylalanine ammonia lyase and peroxidase are also responsible for browning arising from wound as a catalyzer of polyphenol biosynthesis [19]. Because of this exudation of phenolic substances, the explants did not survive and eventually died without regenerating buds. To overcome this, nodal segments were treated with chilled antioxidant and absorbent solution (ascorbic acid, $100 \mathrm{mg} / \mathrm{l}$; citric acid, $50 \mathrm{mg} / \mathrm{l}$; PVP, $25 \mathrm{mg} / \mathrm{l})$ for 10-30 min. Maximum $100 \%$ bud break response with minimum phenolics was obtained when explants were treated with chilled antioxidant and absorbent solution for $15 \mathrm{~min}$. Since, PVP, a polyamide, is known to be the most potent antioxidant, as it absorbs phenols through hydrogen bonding and thus prevents their oxidation [20]. Ajithkumar and Seeni [21] found citric acid and ascorbic acid as potent agent to control oxidative browning. Similar results to overcome phenolic exudation have been reported in Megnifera indica [19] and Terminalia catappa [22].

\subsection{Yellowing of Shoots}

Two major nitrogen source of MS medium had profound effect on axillary shoot proliferation response and leaf fall. The effect of $\mathrm{NH}_{4} \mathrm{NO}_{3}$ and $\mathrm{KNO}_{3}$ on axillary bud break was studied by 
incorporating these salts at different concentration $(1 / 4 \mathrm{x}-1 \mathrm{x})$ in $\mathrm{MS}$ medium supple mented with $2.0 \mathrm{mg} / \mathrm{l} \mathrm{BAP} \mathrm{+} \mathrm{additives}(100 \mathrm{mg} / \mathrm{l}$ of ascorbic acid, $50 \mathrm{mg} / \mathrm{l}$ of citric acid and $25 \mathrm{mg} / \mathrm{l}$ PVP). When full concentration (1x) of $\mathrm{NH}_{4} \mathrm{NO}_{3}$ and $\mathrm{KNO}_{3}$ was used in medium, the newly proliferated shoots dropped their leaves. However, at reduced concentration $(1 \mathrm{x}$ to $1 / 2 \mathrm{x}$ ) of $\mathrm{NH}_{4} \mathrm{NO}_{3}$ and $\mathrm{KNO}_{3}$ in the medium improved bud break percentage from $91.11 \%$ to $100 \%$ and prevented leaf fall and produced healthy shoots. Thus, MS medium with half concentration of $\mathrm{NH}_{4} \mathrm{NO}_{3}(825 \mathrm{mg} / \mathrm{l})$ and $\mathrm{KNO}_{3}(950 \mathrm{mg} / \mathrm{l})$ was the best and referred to as modified MS medium (MMS medium) (Table 4).

The concentration of the salts of basal medium were also found to affect in vitro shoot proliferation and shoot multiplication in $T$. arjuna. Nodal segments containing axillary bud cultured on MS medium showed defoliation but after some repeated subculture, shoots became yellow and died. When nodal segments containing axillary bud were cultured on half concentration of $\mathrm{NH}_{4} \mathrm{NO}_{3}$ and $\mathrm{KNO}_{3}$ salts in MS medium (modified MS medium) it resulted in green, healthy and thick shoots with good in vitro shoot proliferation. Rathore et al. [23] observed that the shoots multiplied on full strength MS medium showed symptoms of hyperhydration and defoliation. The effectiveness of low salt concentration on shoot proliferation and multiplication was also reported in $T$. arjuna $[3,4]$, Citrus limon [23].

\subsection{Leaf Fall}

To study the effect of adenine sulphate as an adjuvant, its three concentration $(25,50,100$ $\mathrm{mg} / \mathrm{l}$ ) were incorporated in MMS (modified MS medium) medium supplemented with $2.0 \mathrm{mg} / \mathrm{l}$ BAP. Results indicated that adjuvating the medium with $50 \mathrm{mg} / \mathrm{l}$ adenine sulphate resulted in $100 \%$ bud break response with retention of leaves and prevention of leaf fall (Table 5). Shoots regenerated from axillary buds were green and healthy. Medium supplemented with $25 \mathrm{mg} / \mathrm{l}$ adenine sulphate resulted in decreased proliferation response. At higher concentration of adenine sulphate $(100 \mathrm{mg} / \mathrm{l})$ in medium, although the percent bud break response was $100 \%$ but number of shoots regenerated was decreased. Therefore, for all experiments $50 \mathrm{mg} / \mathrm{l}$ adenine sulphate was added in MMS medium.

In the present study, adenine sulphate was used as an adjuvant. Adjuvating the medium with 50 $\mathrm{mg} / \mathrm{l}$ adenine sulphate resulted in retention of leaves and prevention of leaf fall. It provides an available source of nitrogen to the cell which can generally be taken up more rapidly than the inorganic nitrogen. Adenine in the form of adenine sulphate can stimulate cell growth and greatly enhance shoot formation [24]. The promotive role of adenine sulphate in shoot induction and multiplication has been emphasized in different woody species namely Bauhinia vahlii [25] and Pithecellobium dulce [8].

Table 3. Effect of antioxidant (100 $\mathrm{mg} / \mathrm{l}$ ascorbic acid and $50 \mathrm{mg} / \mathrm{l}$ citric acid) and absorbent (25 $\mathrm{mg} / \mathrm{PVP}$ ) on browning and leaching. Data recorded after 4 weeks

\begin{tabular}{llll}
\hline Treatment no. & Time duration & Bud break response (\%) & Phenolic exudation \\
\hline 1 & 0 & $62.22 \pm 0.07^{\mathrm{c}}$ & +++++ \\
2 & 10 & $86.66 \pm 0.05^{\mathrm{ab}}$ & ++ \\
3 & 20 & $100.00 \pm 0.00^{\mathrm{a}}$ & + \\
4 & 30 & $73.33 \pm 0.06^{\mathrm{bc}}$ & + \\
\hline \multicolumn{4}{c}{} \\
& $++++=$ Higher phenolic exudation, $++=$ Lower phenolic exudation \\
&
\end{tabular}

Table 4. Effect of $\mathrm{NH}_{4} \mathrm{NO}_{3}$ and $\mathrm{KNO}_{3}$ salts concentration in MS medium on axillary shoot proliferation in $T$. arjuna

\begin{tabular}{llll}
\hline $\begin{array}{l}\mathrm{NH}_{4} \mathrm{NO}_{3} \text { and } \mathrm{KNO}_{3} \text { salts } \\
\text { concentration }\end{array}$ & Response (\%) & Mean shoot number & $\begin{array}{l}\text { Mean shoot length } \\
\text { (cm) }\end{array}$ \\
\hline $1 \mathrm{x}$ & $91.11 \pm 0.04^{\mathrm{a}}$ & $4.68 \pm 0.16^{\mathrm{b}}$ & $0.82 \pm 0.02^{\mathrm{a}}$ \\
$1 / 2 \mathrm{x}$ & $100.00 \pm 0.00^{\mathrm{a}}$ & $5.93 \pm 0.13^{\mathrm{a}}$ & $0.87 \pm 0.02^{\mathrm{a}}$ \\
$1 / 4$ & $77.78 \pm 0.06^{\mathrm{b}}$ & $4.43 \pm 0.20^{\mathrm{b}}$ & $0.75 \pm 0.02^{\mathrm{b}}$ \\
\hline \multicolumn{3}{c}{$A$ value represents mean \pm standard error }
\end{tabular}


Table 5. Effect of adenine sulphate on axillary shoot proliferation of $T$. arjuna. Data recorded after 4 weeks

\begin{tabular}{llll}
\hline $\begin{array}{l}\text { Adenine sulphate } \\
\text { concentration (mg/l) }\end{array}$ & $\begin{array}{l}\text { Bud break response } \\
(\%)\end{array}$ & Mean shoot no. & $\begin{array}{l}\text { Mean shoot length } \\
\text { (cm) }\end{array}$ \\
\hline Control & $86.66 \pm 0.05^{\mathrm{b}}$ & $3.35 \pm 0.16^{\mathrm{c}}$ & $0.67 \pm 0.02^{\mathrm{b}}$ \\
25 & $95.55 \pm 0.03^{\mathrm{a}}$ & $3.86 \pm 0.18^{\mathrm{bc}}$ & $0.72 \pm 0.02^{\mathrm{b}}$ \\
50 & $100.00 \pm 0.00^{\mathrm{a}}$ & $5.31 \pm 0.15^{\mathrm{a}}$ & $0.83 \pm 0.02^{\mathrm{a}}$ \\
100 & $100.00 \pm 0.00^{\mathrm{a}}$ & $4.28 \pm 0.20^{\mathrm{b}}$ & $0.80 \pm 0.02^{\mathrm{a}}$ \\
\hline \multicolumn{4}{c}{ A value represents mean \pm standard error }
\end{tabular}

$A$ value represents mean \pm standard error

\section{CONCLUSION}

In conclusion, culture establishment is the first and most challenging part in micropropagation method for any plant species, especially in woody plants, where many problems can occur. However, the present study provides useful information and techniques to overcome the problems arising from the in vitro culture establishment of $T$. arjuna to reach efficient and large scale production of Arjuna to preserve its medicinal properties and uses.

\section{ACKNOWLEDGEMENTS}

The authors are thankful to Council of Scientific and Industrial Research (CSIR), New Delhi for the financial support and Director, Arid Forest Research Institute (AFRI), Jodhpur, India for providing lab facilities to carry out this research.

\section{COMPETING INTERESTS}

Authors have declared that no competing interests exist.

\section{REFERENCES}

1. Sharma J, Gairola S, Gaur RD, Painuli RM. The treatment of jaundice with medicinal plants in indigenous communi ties of the Sub-Himalayan region of Uttara khand, India. Journal of Ethnophar Macology. 2012;143:262-291.

2. Kumar GP, Navya K, Ramya EM, Venkataramana M, Anand T, kumar KRA. DNA damage protecting and free radical scavenging properties of Terminalia arjuna bark in PC-12 cells and plasmid DNA. Free Radicals and Antioxidants. 2013;3:35-39

3. Pandey S, Singh M, Jaiswal U, Jaiswal VS. Shoot initiation and multiplication from a mature tree of Terminalia arjuna roxb. In Vitro Cellular and Developmental BiologyPlant. 2006;42:389-393.
4. Gupta AK, Harish, Rai MK, Phulwaria M, Agarwal T, Shekhawat NS. In vitro propagation, encapsulation and genetic fidelity analysis of Terminalia arjuna: A cardioprotective medicinal tree. Applied Biochemistry and Biotechnology. 2014; 173(6):1481-1494.

5. Choudhary M, Jaiswal S, Singh R, Arya ID, Arya SA. Micropropagation protocol for mass multiplication of Terminalia arjuna a valuable medicinal tree. Advances in Forestry Science. 2015;2:1-6.

DOI: 10.34062/afs.v2i1.2107

6. Choudhary M, Gehlot A, Arya ID, Arya S. Influence of different auxin treatment on ex vitro rooting in in vitro regenerated micro shoots of Terminalia arjuna (Arjun). Journal of Pharmacognosy and Phytochemistry. 2018;7:3079-3082.

7. Choudhary M, Arya ID, Arya S. Factors affecting ex vitro rooting in micro propagated shoots from nodal explants of Terminalia arjuna. Current Journal of Applied Science and Technology. 2020; 39:92-97.

8. Goyal P, Kachhwaha S, Kothari SL. Micropropagation of Pithecellobium dulce (Roxb.) Benth - A multipurpose leguminous tree and assessment of genetic fidelity of micropropagated plants using molecular markers. Physiology and Molecular Biology of Plants. 2012;18(2): 169-176.

9. Ram B, Rathore TS, Bopanna BD. An efficient protocol for micropropagation and genetic stability analysis of Melia dubia Cav. - An important multipurpose tree. International Journal of Current Micro biology and Applied Sciences. 2014;3 (7):533-544.

10. Kanungo S, Pradhan C, Sahoo SL, Sahu RK. Role of auxins in the in vitro rooting and micropropagation of Holarrhena antidysenterica Wall., a woody aromatic medicinal plant, through nodal explants 
from mature trees. Journal of Medicinal Plants Research. 2012;6(31):4660-4666.

11. Arya ID, Nautiyal S, Arya S. Tissue culture studies on clonal variations in micro propagation of Dalbergia sissoo. International Journal of Biotechnology Research. 2013;1(4):58-70.

12. Phulwaria M, Ram K, Gahlot $P$, Shekhawat NS. Micropropagation of Salvadora persica- A tree of arid horticulture and forestry. New Forests. 2011;42:317-327.

13. Rathore V, Shekhawat NS, Singh RP, Rathore JS, Dagla HR. Cloning of adult tree of Jamun (Syzygium cuminii). Indian Journal of Biotechnology. 2004;3:241-245.

14. Saha D. Studies on factors influencing node culture establishment during in vitro shoot multiplication from mature Schleichera oleosa (Lour.) Oken tree. Indian Journal of Natural Products and Resources. 2013;4(1):102-109.

15. Purohit SD, Joshi P, Tak K, Nagori R. Development of high efficiency micropro pagation protocol of an adult tree- Wrightia tomentosa. Plant Biotechnology and Molecular Markers. 2005;217-227.

16. Vibha JB, Shekhawat NS, Mehandru P, Dinesh R. Rapid multiplication of Dalbergia sissoo Roxb: A timber yielding tree legume through axillary shoot proliferation and $e x$ vitro rooting. Physiology and Molecular Biology of Plants. 2014;20 (1):81-87.

17. Chitbanchong W, Sardsud V, Whangchai K, Koslanund R, Thobunluepop P. Control of rotting and browning of Longan fruit cV. Biew Kiew after harvested by sulphur dioxide treatment under various storage temperatures. Pakistan Journal of Biological Sciences. 2009;12:1438-1447.
18. Murata M, Tsurutani M, Hagiwara $S$, Homma S. Subcellular location of polyphenol oxidase in Apples. Bioscience, Biotechnology and Biochemistry. 1997;61: 1495-1499.

19. Krishna H, Sairam RK, Singh SK, Patel VB, Sharma RR, Grover M, Nain L, Sachdev A. Mango explant browning: Effect of ontogenic age, mycorrhization and pre-treatments. Scientia Horticulturae. 2008;118(2):132-138.

20. Pati R, Chandra R, Chauhan UK, Mishra $\mathrm{M}$, Srivastava N. In vitro clonal propagation of bael (Aegle marmelos Corr.) CV. CISHB1 through enhanced axillary branching. Physiology and Molecular Biology of Plants. 2008;14(4):337-346.

21. Ajeethkumar, Seeni S. Rapid clonal multiplication through in vitro axillary shoot proliferation of Aegle marmelos (L) Corr., a medicinal tree. Plant Cell Reports. 1998; 17(5):422-426.

22. Phulwaria M, Ram K, Harish, Gupta AK, Shekhawat NS. Micropropagation of mature Terminalia catappa (Indian Almond), a medicinally important forest tree. Journal of Forest Research. 2012;17: 202-207.

23. Rathore JS, Rathore MS, Singh M, Singh RP, Shekhawat NS. Micropropagation of mature tree of Citrus limon. Indian Journal of Biotechnology. 2007;6:239-244.

24. Murashige T. Plant propagation through tissue culture. Annual Review of Plant Physiology. 1974;25:135-166.

25. Dhar U, Upreti J. In vitro regeneration of a mature leguminous liana (Bauhinia vahlii Wight \& Arnott). Plant Cell Reports. 1999; 18:664-669.

(c) 2020 Choudhary et al.; This is an Open Access article distributed under the terms of the Creative Commons Attribution License (http://creativecommons.org/licenses/by/4.0), which permits unrestricted use, distribution, and reproduction in any medium, provided the original work is properly cited.

Peer-review history:

The peer review history for this paper can be accessed here: http://www.sdiarticle4.com/review-history/64676 